\title{
Ja, de penga
}

\begin{abstract}
Hver høst starter en ny gruppe håpefulle medisinstudenter på universitetene. De vet at de etter endt utdanning vil kunne få en anstendig lønn. Men skal vi tro denne artikkelen, var det ikke nødvendigvis slik i 1890 (Tidsskr Nor Lægeforen 1890; 10: 258). Fattig eller ikke, kontingenten til Legeforeningen burde man passe på å betale - det ble offentliggjort i Tidsskriftet.
\end{abstract}

\section{Kontant betaling.}

(Af Vedeler).

Der er ikke en eneste læge her i landet, som i de siste 28 aar har ved sin medicinske kundskab alene tjent sig rig, og dog er landets velstand gaaet overmaade frem, og der findes folk paa alle kanter, som er blevne rige ved sin specielle dyktighed. Der er nogle læger, men de kan tælles paa de 10 fingre, som har erhvervet sig saa stor en velstand ved sin praksis alene, at de ved sin død kan gaa rolig bort fra sine efterladte. I flere af disse tilfælde har dette alene kunnet ske derved, at de har havt nogen privat formue eller en nogenlunde godt aflønnet post, som har dækket en større del af deres udgifter. Alle de øvrige læger har levet næsten fra haand til mund og kan ikke vente en sorgfri alderdom; den eneste chance, de har, er, at lægen som oftest dør forholdsvis ung.

(...) Summa summarum: af 54 afdøde læger har kun 1 tjent sig velstand, altsaa 1,6\%. Der er 500 læger i hele Norges land; man behøver vist ikke de ti fingre for at tælle dem, som kan rolig gaa bort fra sin familie, og det saa meget mindre som der i de samme 10 aar er 5 læger, som faar understøttelse paa grund af sygdom eller alderdom. Nu kommer der nok en forværrende omstændighed til, nemlig de medicinske studenters store antal for tiden. Faa udenbys læger har i grunden noget videre begreb om dette; men de burde have været tilstede ved de siste forelæsninger for doktorgraden. Det store anatomiske læseværelse var saa opfyldt af studenter, at der ikke var plads til at sidde, og hele gulvet stod pakkende fuldt, og dette var væsentlig dog kun dem, som læser til anden eller tredje afdeling; de fleste af dem til første afdeling var ikke tilstede. Det er ikke lystige udsigter, som staar for den kommende slegt. (...)

\section{Kontingent}

til lægeforeningen er $\mathrm{i}$ januar maaned indbetalt af folgende medlemmer:

$\begin{array}{ll} & \text { For I } 889 . \\ \text { Borge, C. J. } & \text { Lund, Ivar. } \\ \text { Bryn, Th. Th. } & \text { Moe, A. O. } \\ \text { Ellefsen, K. A. } & \text { Mohn, G. O. } \\ \text { Freng, H. } & \text { Poulsson, E. C. } \\ \text { Holm, J. W. K. } & \text { Torgersen, N. } \\ \text { Kaurin, Edv. } & \end{array}$

For 1890.

Herlofsen, C. Th. Nannestad, J. Klingenberg, K.Th. Rasch, J. G. Krohn, J. P. B. Sommerschild, B. Lund, C. A. D. Vogt, J. Møinichen, J. L. Vogt, P. H.

I forbindelse med ovenstaaende kvittering for de $\mathrm{i}$ sidste maaned modtagne medlemskontingenter, hvilken for fremtiden vil indrykkes $\mathrm{i}$ hvert nummer af tidsskriftet, finder sekretæren at burde bemerke, at flere medlemmer ved indsendelsen af kontingenten viser sig at staa $\mathrm{i}$ den formening, at de betaler for aaret 1890 , mens regnskabet udviser, at de endnu staar til rest for I889. Dette hidhører derfra, at mange medlemmer ikke har været opmerksomme paa, at aaret I886 paa det konsti. tuerende mode i Kristiania blev besluttet at skulle gjælde for fuldt regnskabsaar. 